\title{
A COMPARISON OF MATCH ANALYSIS RESULTS OF 2015-2016 SPOR TOTO SUPER LEAGUE TEAMS ${ }^{1}$
}

\section{5-2016 SEZONU SPOR TOTO SÜPER LİG TAKIMLARININ MAÇ ANALIZI SONUÇLARININ KARŞILAŞTIRILMASI}

\author{
Ali Onur CERRAH', Yılmaz YÜKSEL ${ }^{2}$, Ramazan TAŞÇIOĞLU ${ }^{3}$ \\ 1-2-3 Anadolu University, Faculty of Sport Sciences, Eskişehir / Turkey
}

Öz: Bu araştırma 2015-2016 Spor Toto Süper Lig'de yer alan takımların bölgelere göre asist öncesi pas, asist ve gol skorları verilerini gol amaçlı oyun anlayışlarını değerlendirmek amacıyla yapılmıştır. Bu araştırmada kullanılan veriler, 2015-2016 Spor Toto Süper Lig'de yer alan takımların (18 takım) maç (306 maç) özetlerinin LİG TV web sitesi üzerinden iki araştırmacı tarafından izlenmesi ile elde edilmiştir. Verilerin istatistiksel analizlerinde SPSS 22.0 programı kullanılmıştır. Yapılan Shapiro-Wilk testine göre normal dağılım göstermeyen veriler non-parametrik testlerden Kruskal Wallis Testi ve Kruskal Wallis çoklu karşılaştırma testi ile analiz edilmiştir. Bu sonuçlara göre, takımların müsabakalar esnasında yaptıkları diğer alanlar bölgesinden asist öncesi paslarda, gol bölgesinden asistlerde, serbest vuruştan, karambolden, orta yapılan bölgeden, gol bölgesinden ve gol vuruş alanı 1 bölgesinden atılan gollerde takım grupları açısından etki değeri çok büyük anlamlı farklar bulunmuştur. Sonuç olarak, özellikle ülkemizdeki takımların en büyük sorunlarından biri üçüncü bölge hücum çeşitliliği olduğu düşünüldüğünde, araştırma bulguları antrenör ve sporculara yol gösterir niteliktedir. Üst sıralardaki takımların ceza sahası içerisinde yer alan altın bölgeyi alt sıralardaki takımlara göre daha etkin kullanmaları, bu oyun anlayışının antrenör ve sporcular açısından başarılı sonuçlar sağlayabileceği çıkarımı yapılabilir.

Anahtar Kelimeler: Futbol, Maç Analizi, Altın Bölge, Hücum Futbolu, Gol Bölgesi
Abstract: This study aimed to investigate pre-assist passes, assists and goal scores from different zones by Sport Toto Super League teams in 2015-2016 to reflect their football understanding aiming to score goals. All of the matches (totally 306 matches) of the 2015-2016 Spor Toto Super League were analyzed on LIG TV website by the two scientists. The SPSS 22.0 was used for statistical analyses. According to normality test (Shapiro-Wilk), non-parametric Kruskal Wallis Test was used in order to identify differences. According to the results, the pre-assist passes made by the teams in other zones during the games, the assists made in goal zones, the goals scored from free kicks, the goals scored from carom positions, the goals made through the crossed balls, the goals scored from the goal zones, the goals scored from the goal shoot zone 1 were found to significantly difference with very high effect size for team groups. In brief, when the offense diversity in the 3rd zone which is one of the biggest problems of the teams in our country is considered, the research findings are suggested to be a guiding light for trainers and players. The fact that the teams at top ranks are better at using the gold zone within the penalty area compared to those at the bottom ranks can be used to suggest that this play style can offer successful outcomes for trainers and players.

Key Words: Soccer, Match Analysis, Gold Zone, Attacking Football, Goal Zone

Doi: $10.17363 /$ SSTB.20162124004

(1) Corresponding Author: Yulmaz, YÜKSEL, Anadolu University, Faculty of Sport Sciences, , Eskişehir / Turkey yilmazyuksel@anadolu.edu.tr Received: 23.09.2016 Date of Arrangement 11.30.2016 Accepted: 20.12.2016 Type ofarticle (Research -Application) Conflict of Interest: None / "None of Ethics Committee" 


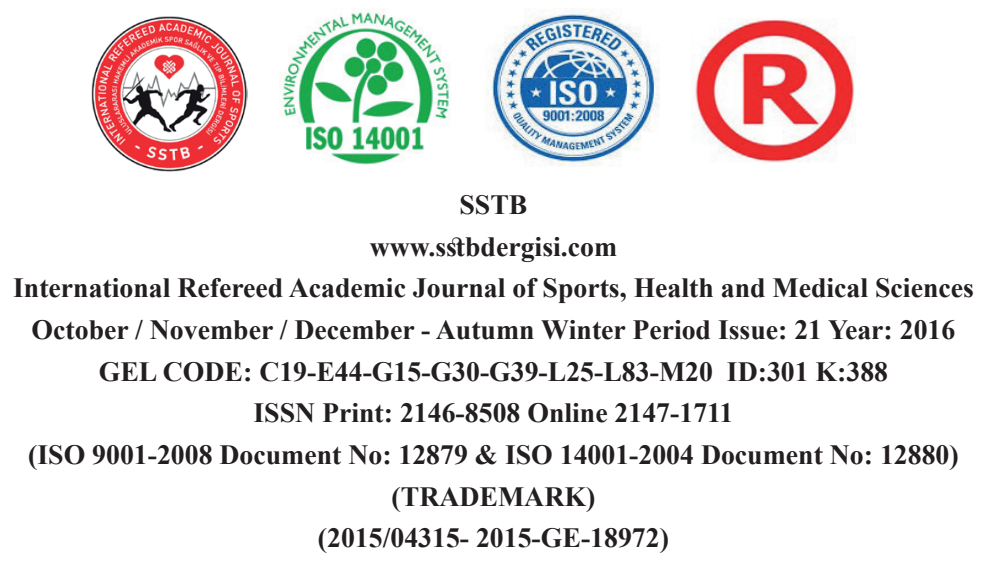

\section{INTRODUCTION}

As in all branches of sports, one of the factors affecting footballers' performances and successes is their physical capacities (Rankovic et. al, 2010). Because football is a sport with low density overloads (Drust, 2009:24) as well as high aerobic and anaerobic effort overloads (Orendurff et. al., 2010: 2683; Aşçıet.al, 2009: 48; Alghannam, 2012: 65).Another factor affecting footballers' performances and successes in matches is their technical and tactical capacities which are considered to be a major determinant in footballers' game performances (Carling et.al, 2005: 18).

Evaluation of players' technical, tactical and physical performances through qualitative and quantitative methods is very important for players to reach their technical, tactical and motivational fitting levels (Uğraş et. al, 2002: 243). Team performances can also be changed through match analysis methods which also benefit from inferential statistics as well as descriptive statistics (Cengiz and Kılınç, 2002: 351; Işık and Gençer, 2007: 102). In football, match analysis methods are employed to investigate parameters regarding players' technical, tactical and physical capacities (Sarmento et. al, 2014: 1). Match analysis is about objective recording of the information regarding the matches and obtaining accurate statistical and numerical values to find out performance parameters of the players in games. Match analysis which is mostly conducted with the use of voiced observation, manual or computerized techniques are considered to be significant factors affecting performances and successes of players in football (Müniroğlu, 2009: 17). In addition, it is also used by trainers in obtaining objective data and in guiding teams under the collected data (İmamoğlu et. al. 2015: 161), such as the technical performance parameters e.g. on target shoot and pass control (Moura et.al 2014: 1881).

In some of the studies conducted with the use of match analysis methods in the literature, the number of shoots, the rate of on target shoots and ball control rates (Castellano et. al. 2012: 141), set-piece goals (Cerrah and Gürol, 2011: 79) and the goals set in world cups and leagues(De Branda and Lopez, 2012: 121) were investigated. Similarly, according to the findings in the literature, it is commonly seen that aiming to attack affects match results (Winter and Pfeiffer, 2016: 486) and shoot on goals are largely achieved within penalty area (İmamoğlu et. al 2007: 157,Sönmeyenmakas 2008 46).

Whereas there are many studies in the literature investigating penalty area and the goals set, the number of studies investigating the organization of the set goals which is a signal of tactical understanding in which 


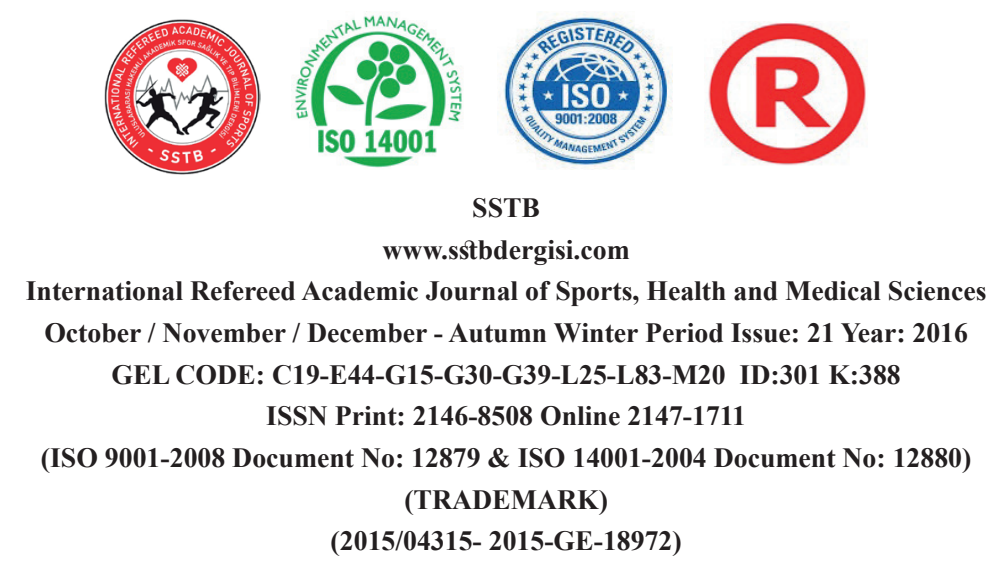

assists and the pre-assist zones is limited in the literature. This study which was conducted within this scope aimed to investigate the goals set from carom or free kicks, penalty as well as corner kicks, pre-assist passes, assists and goal scores from different zone by Sport Toto Super League teams in 2015-2016 to reflect their football understanding aiming to score goal.

\section{METHOD}

\section{Research Design}

This study used a qualitative content analysis method which is a type of content analysis out of the qualitative research techniques commonly used to measure the frequency and diversity of the messages within the data regarding the written or electronic communication with a positivist perspective
(Yıldırım and Şimşek, 2003: 162; Güler et. al, 2015: 337).

\section{Data Collection}

The data used in this study was collected by the two researchers watching the match highlights of Super League teams (306 matches) in 2015-2016 football season (18 teams) on the web site of LIG TV Corner kicks, pre-assist passes, assists and goal scores as well as the goals scored from carom and free kicks in the viewed match highlights were recorded on Microsoft Excel 2013 under pre-determined headings. The recordings of three parameters (pre-assist pass, assist and goal) were redescribed by the researchers adapting from the studies of John Bilton on match analysis (Bilton and Usher, 2014) (Figure 1). 

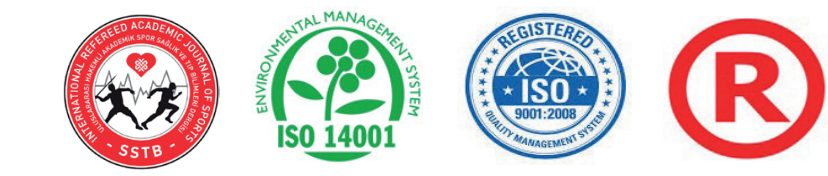

SSTB

www.sstbdergisi.com

International Refereed Academic Journal of Sports, Health and Medical Sciences October / November / December - Autumn Winter Period Issue: 21 Year: 2016

GEL CODE: C19-E44-G15-G30-G39-L25-L83-M20 ID:301 K:388

ISSN Print: 2146-8508 Online 2147-1711

(ISO 9001-2008 Document No: 12879 \& ISO 14001-2004 Document No: 12880)

(TRADEMARK)

(2015/04315- 2015-GE-18972)

\section{Figure 1. Game Zones}

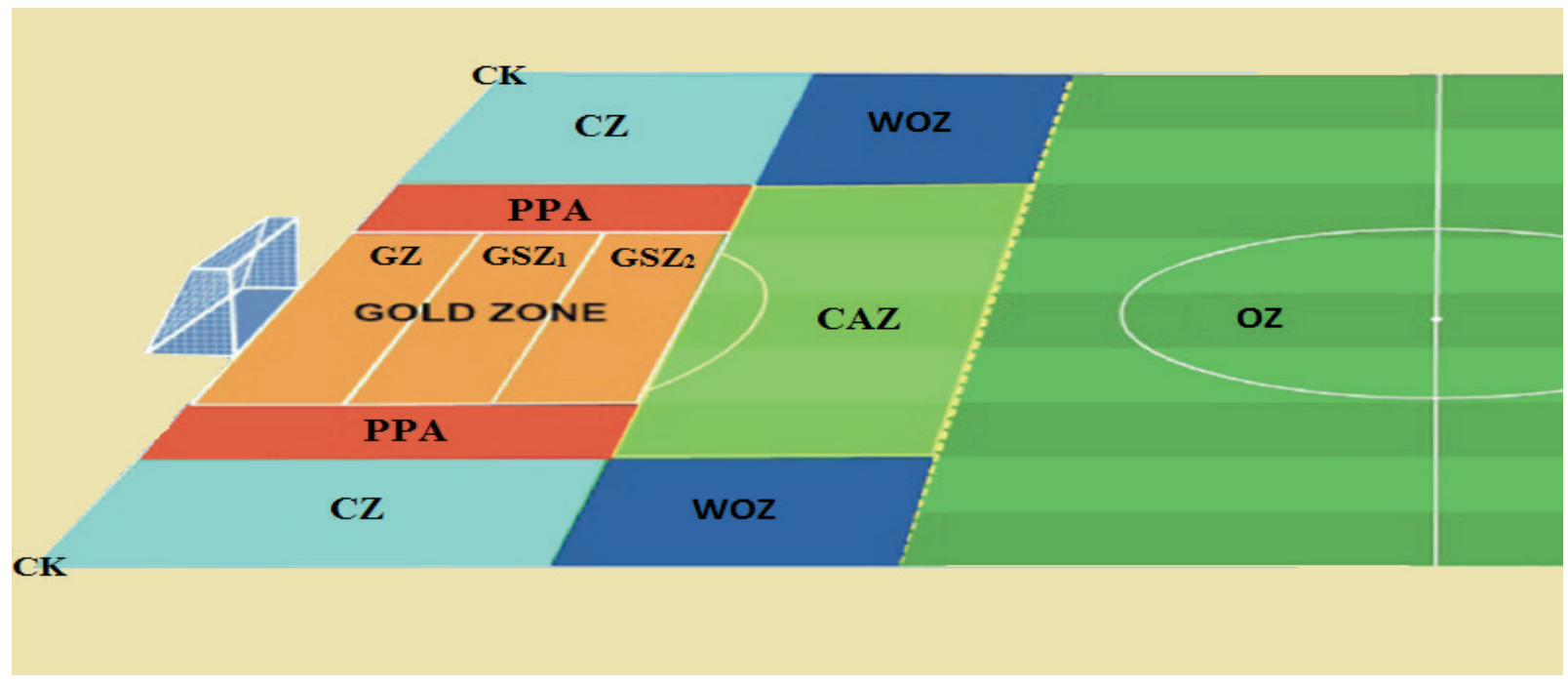

GOZ: Gold Zone, CK: Corner Kick, WOZ: Wide Offensive Zone, OZ: Other Zones, CAZ: Central Attack Zones, CZ: Crossing Zone, PPA: Short Pass Made Into Penalty Area, GZ: Goal Zone, GSZ : Goal Shoot Zone1, GSZ: Goal Shoot Zone2, CRM: Carom, PEN: Penalty, FK: Free Kicks

To increase the reliability of the data obtained from the content analysis, it is suggested to meet the criteria of stability, reproductively and accuracy. Therefore, to increase the reliability of the data obtained with this study, the collected data were classified under pre-

determined and standardized headings by the researchers. To increase the validity of the collected data, the results and fittings between the categories were examined (Güler et. al., 2015: 362-363). To do that, the researchers looked for a consensus on the contradictive issues. 

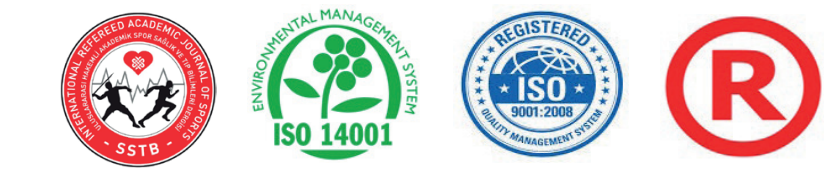

SSTB

www.sstbdergisi.com

International Refereed Academic Journal of Sports, Health and Medical Sciences

October / November / December - Autumn Winter Period Issue: 21 Year: 2016

GEL CODE: C19-E44-G15-G30-G39-L25-L83-M20 ID:301 K:388

ISSN Print: 2146-8508 Online 2147-1711

(ISO 9001-2008 Document No: 12879 \& ISO 14001-2004 Document No: 12880)

(TRADEMARK)

(2015/04315- 2015-GE-18972)

Figure 2. Team Groups Depending on the $34^{\text {th }}$ Week of 2015-2016 Spor Toto Super League

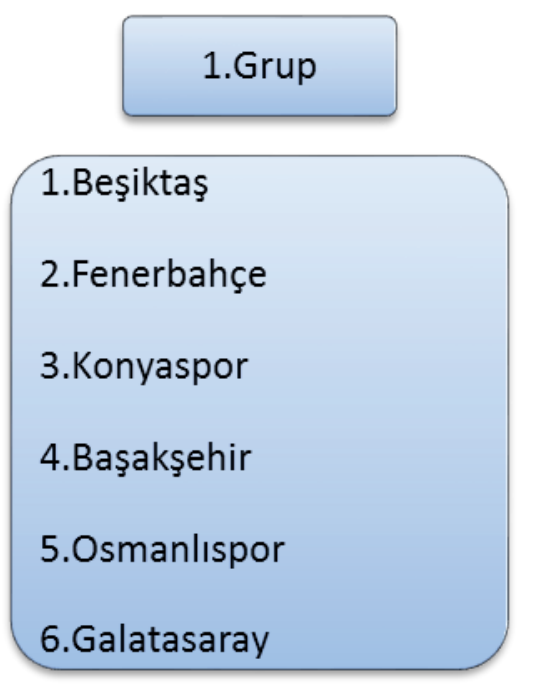

\section{Grup}

\section{Kasımpaşa}

8.Akhisar Belediye

9.Antalyaspor

10.Gençlerbirliği

11.Bursaspor

12.Trabzonspor
3.Grup

13.Çaykur Rizespor

14.Gaziantepspor

15.Kayserispor

16.Sivasspor

17.Eskişehirspor

18.Mersin İdman Yurdu
The teams which were listed in this study based on their total scores at $34^{\text {th }}$ week of 2015-2016 Spor Toto Super League were grouped into three categories by the researchers as the first group aiming to compete for international tournaments (UEFA Champions League and UEFA Europa League), the second group already ensuring to remain in the league without any aim for any international tournaments and the third group which fight in the drop zone to stay in the league in the last weeks of the season (Figure 2).

\section{Statistical Analysis}

SPSS 22.0 programme was used in the analysis of the collected data in the study. According to the Shapiro-Wilk test for checking normality, Kruskal Wallis (KW) and KW multiple comparison tests which are some of the non-parametric tests were used for non-normally distributed data. 


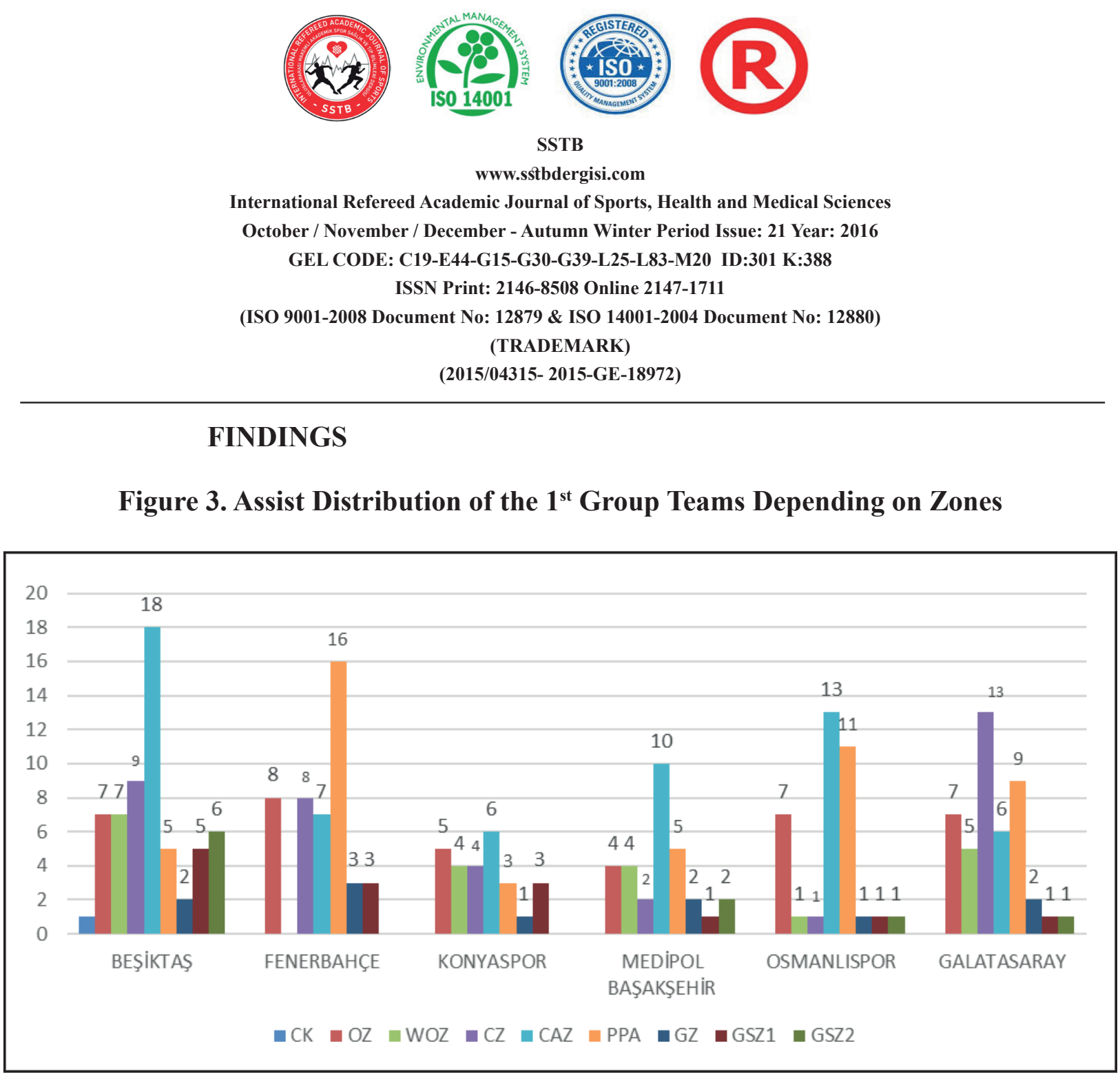

Figure 3. Assist Distribution of the $1^{\text {st }}$ Group Teams Depending on Zones

According to the data presented in Figure 3, the team winning the championship in the 1 . Group teams (Beşiktaş) was found to make the assists (18 assists) mostly from CAZ in the games. In addition, the team in the second rank at the end of the season (Fenerbahçe) was found to make the assists mostly from PPA (16 assists). The teams competing in the 1st group were found to make assists mostly in CAZ (60 assists) and PPA (49 assists). 

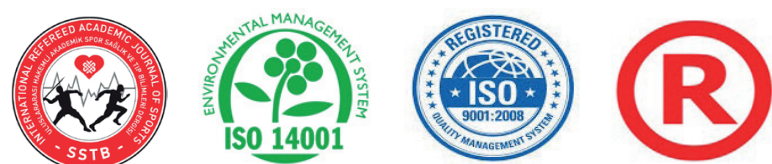

SSTB

www.sstbdergisi.com

International Refereed Academic Journal of Sports, Health and Medical Sciences

October / November / December - Autumn Winter Period Issue: 21 Year: 2016

GEL CODE: C19-E44-G15-G30-G39-L25-L83-M20 ID:301 K:388

ISSN Print: 2146-8508 Online 2147-1711

(ISO 9001-2008 Document No: 12879 \& ISO 14001-2004 Document No: 12880)

(TRADEMARK)

(2015/04315- 2015-GE-18972)

Figure 4. Assist Distribution of $2^{\text {nd }}$ Group Teams Depending on Zones

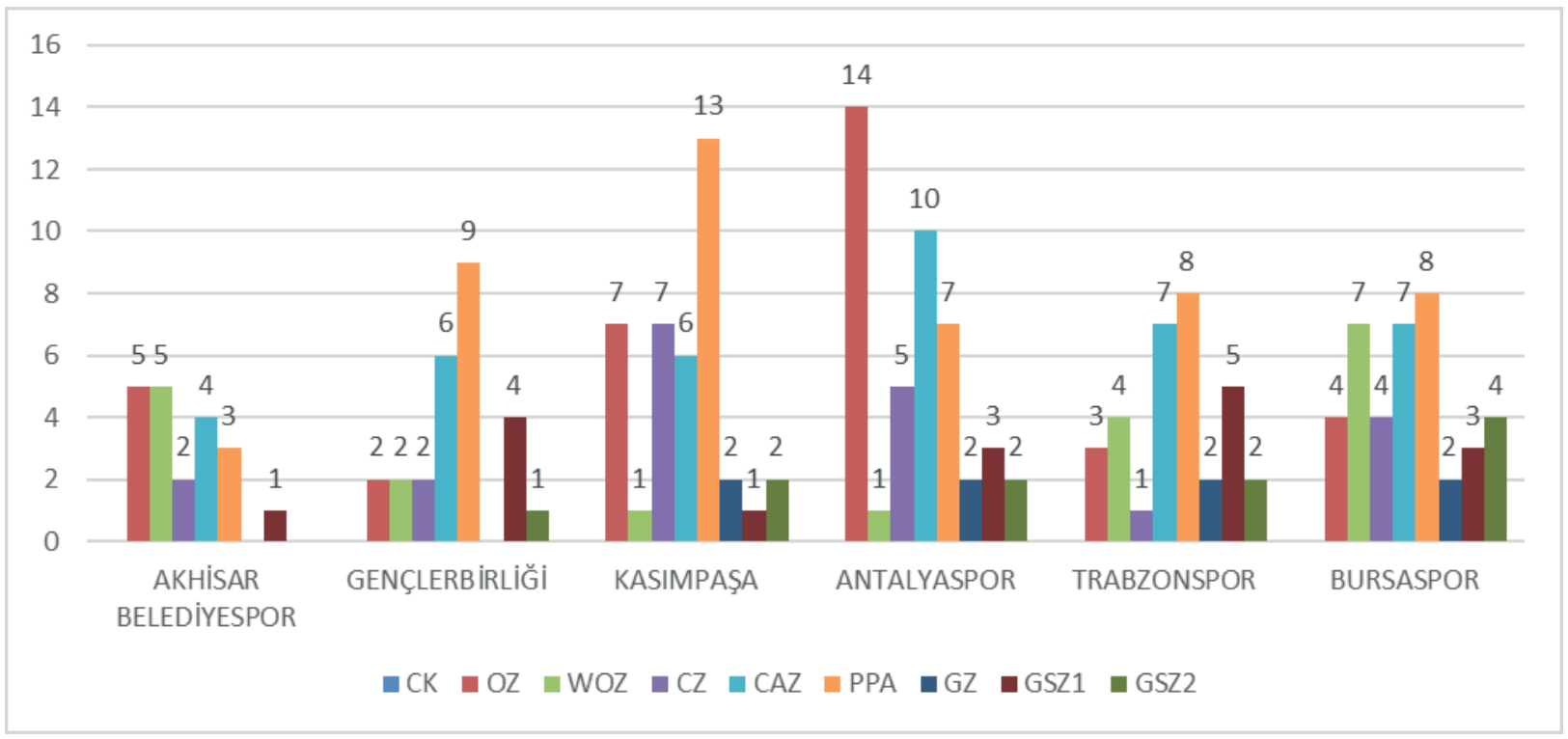

According to the data in Figure 4, the zones where the teams in the 2 nd group make the most assists when their matches between each other were considered, were found to be in PPA (48 assists) and CAZ (40 assists).

Figure 5. Assist Distribution of $3^{\text {rd }}$ Group Teams Depending on Zones

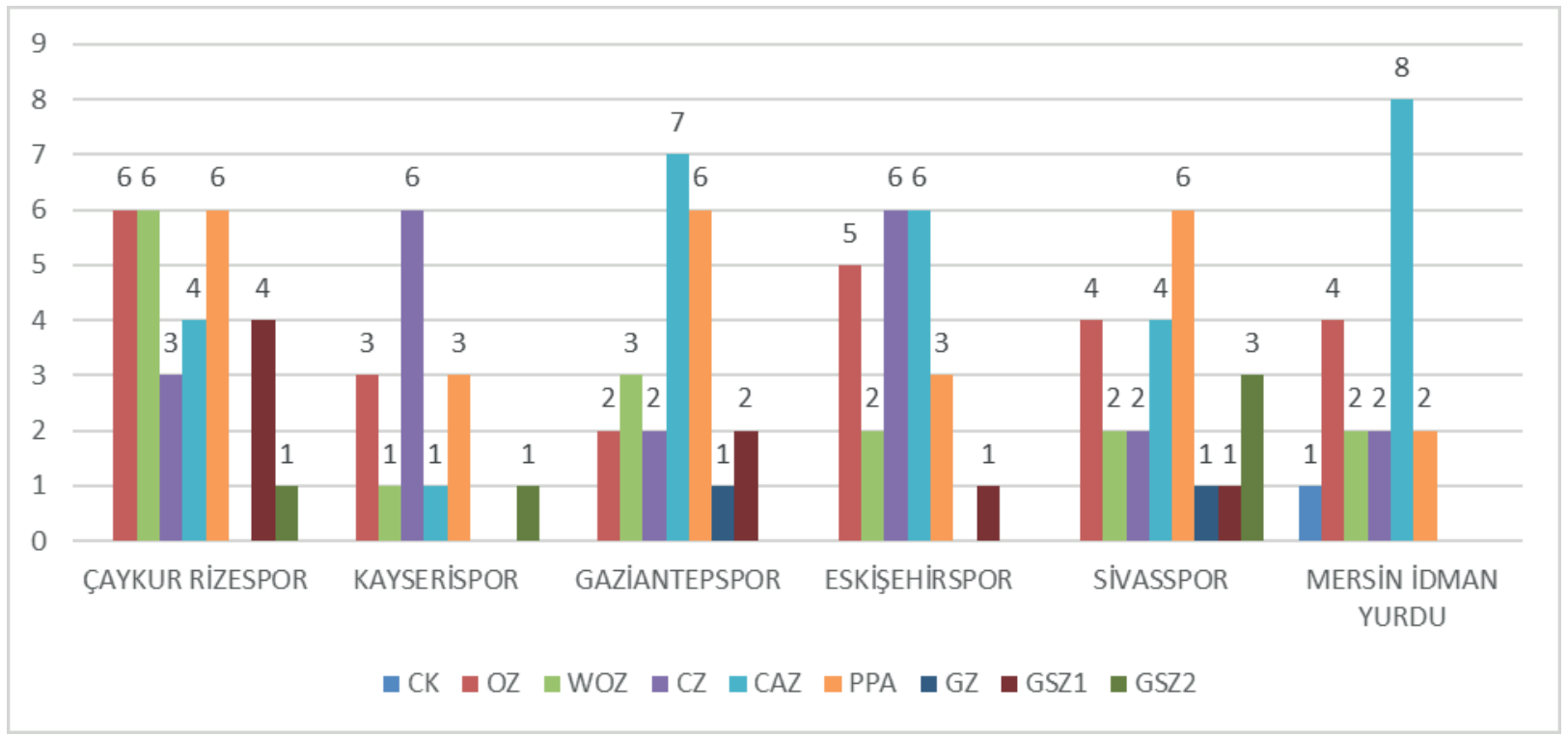




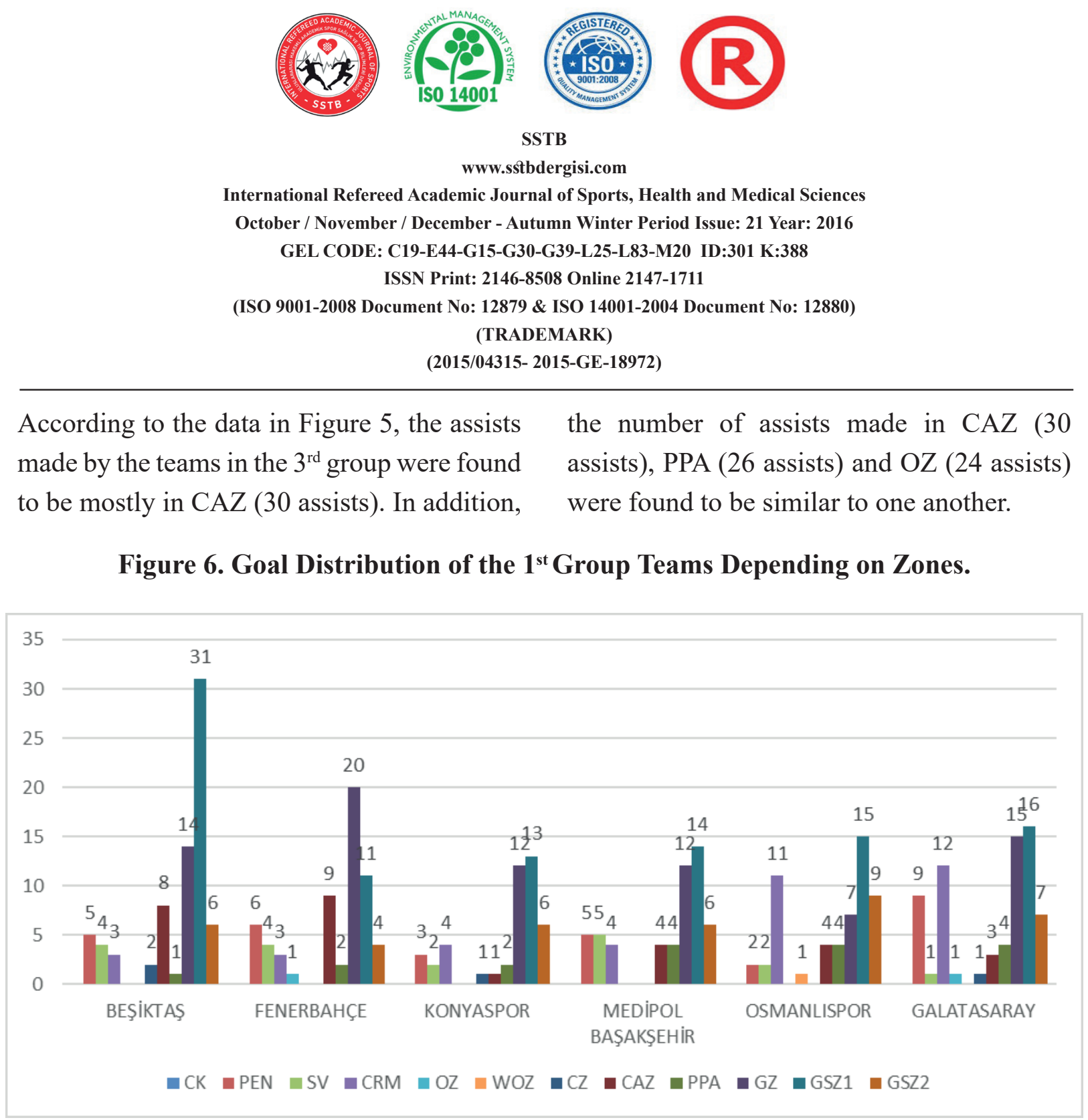

According to the data in Figure 5, the assists made by the teams in the $3^{\text {rd }}$ group were found to be mostly in CAZ (30 assists). In addition,

Figure 6. Goal Distribution of the $1^{\text {st }}$ Group Teams Depending on Zones.

According to the data in Figure 6, the team winning the championship of the league in the $1^{\text {st }}$ group (Beşiktaş) was found to score goals in $\mathrm{GSZ}_{1}$ most (31 goals), the team in the second rank at the end of the season
(Fenerbahçe) was found to score goal from GZ most (20 goals). The zones where the teams in the $1^{\text {st }}$ group scored most were found to be GSZ (100 goals) and GZ (80 goals). 

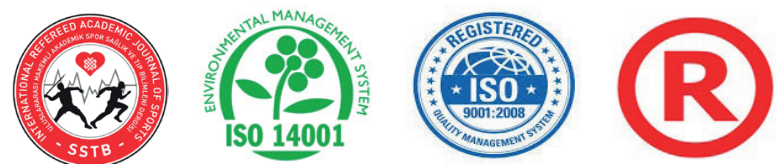

SSTB

www.sstbdergisi.com

International Refereed Academic Journal of Sports, Health and Medical Sciences October / November / December - Autumn Winter Period Issue: 21 Year: 2016 GEL CODE: C19-E44-G15-G30-G39-L25-L83-M20 ID:301 K:388 ISSN Print: 2146-8508 Online 2147-1711

(ISO 9001-2008 Document No: 12879 \& ISO 14001-2004 Document No: 12880) (TRADEMARK)

(2015/04315- 2015-GE-18972)

Figure 7. Goal Distribution of the $2^{\text {nd }}$ Group Teams Depending on Zones.

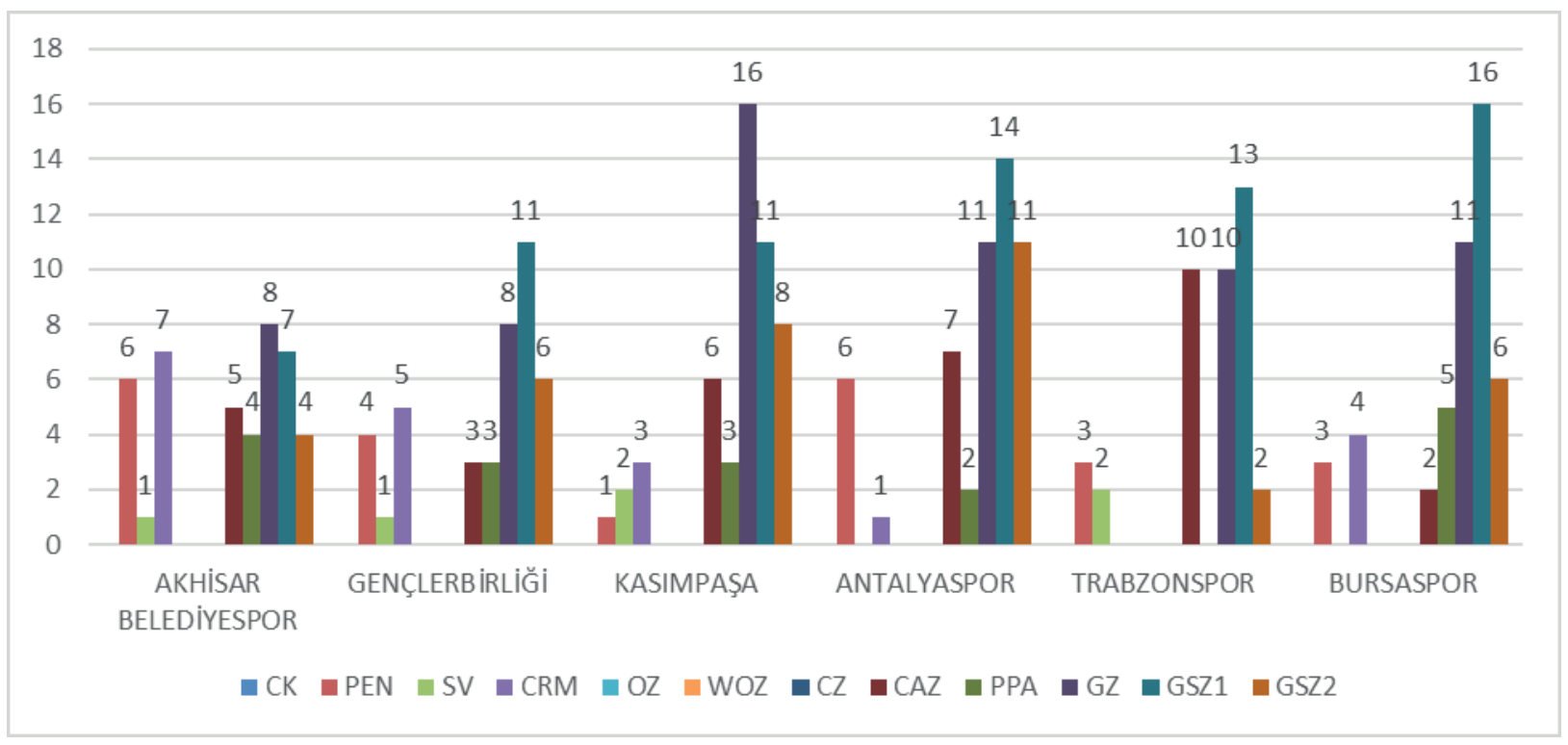

According to the data in Figure 7, the goals scored by the teams in the $2^{\text {nd }}$ group were found to be, respectively, from $\mathrm{GSZ}_{1}$ (72 goals) and GZ (64 goals).

Figure 8. Goal Distribution of the $3^{\text {rd }}$ Group Teams Depending on Zones.

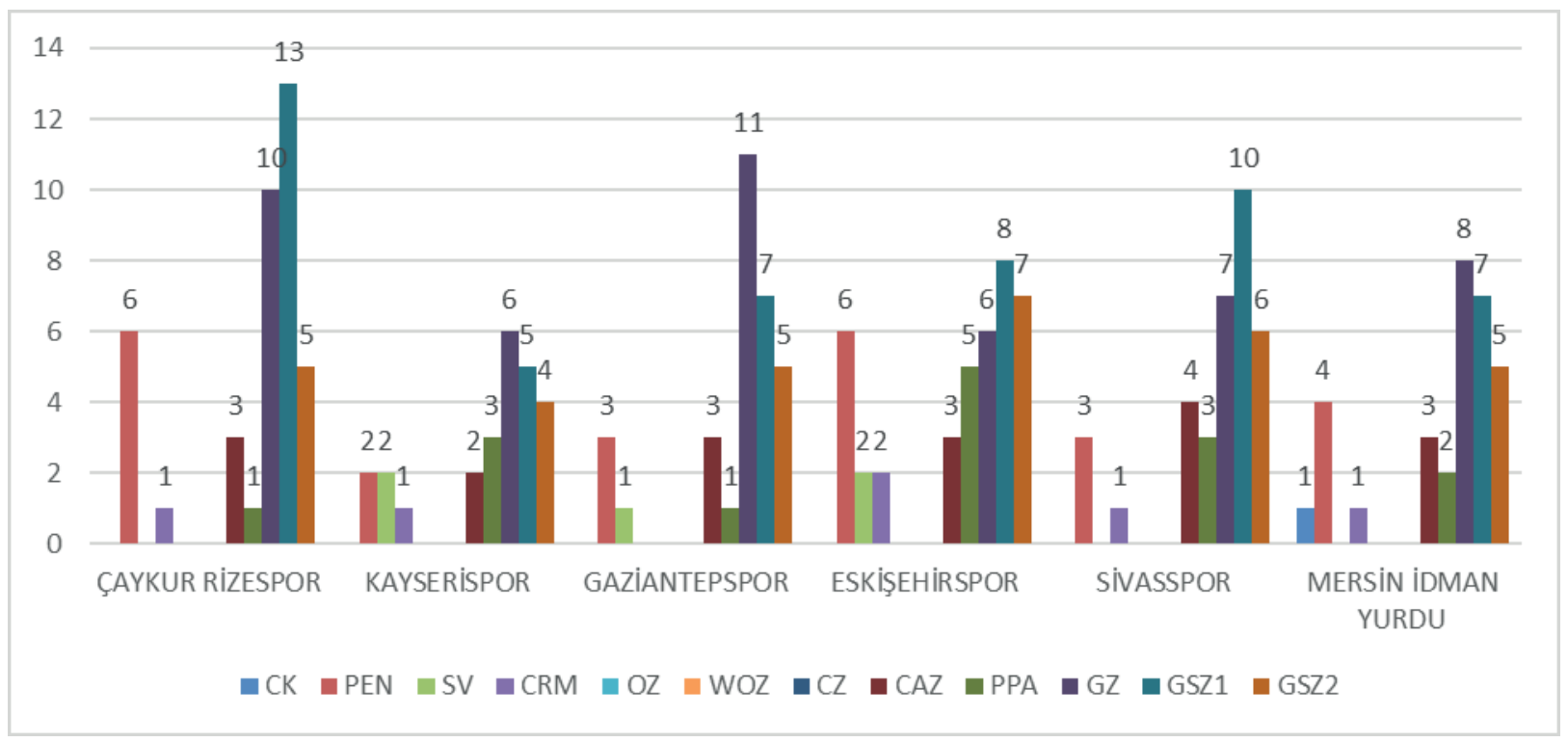


www.sstbdergisi.com

International Refereed Academic Journal of Sports, Health and Medical Sciences October / November / December - Autumn Winter Period Issue: 21 Year: 2016

GEL CODE: C19-E44-G15-G30-G39-L25-L83-M20 ID:301 K:388

ISSN Print: 2146-8508 Online 2147-1711

(ISO 9001-2008 Document No: 12879 \& ISO 14001-2004 Document No: 12880)

(TRADEMARK)

(2015/04315- 2015-GE-18972)

According to the data in Figure 8, the goals scored by the teams in the $3^{\text {rd }}$ group were found to be from $\mathrm{GSZ}_{1}$ (50 goals) and GZ (48 goals). In addition, the goals scored by the
3 teams in the $3^{\text {rd }}$ group and being dropped from the league were found to be from GZ (48 goals), $\mathrm{GSZ}_{1}$ (50 goals) and $\mathrm{GSZ}_{2}(32$ goals).

Table 1. Comparison Pre-Assist Passes, Assists and Goals of the Team Groups Depending on the Zones

\begin{tabular}{|c|c|c|c|c|c|c|c|c|c|c|c|c|}
\hline \multirow{2}{*}{$\begin{array}{c}\text { Team } \\
\text { Groups }\end{array}$} & \multirow{2}{*}{ Zone } & \multirow{2}{*}{$\mathbf{n}$} & \multirow{2}{*}{ Min } & \multirow{2}{*}{$\operatorname{Max}$} & \multirow{2}{*}{ Median } & \multirow{2}{*}{ MeanRank } & \multirow{2}{*}{ SD } & \multicolumn{2}{|c|}{ Percentage } & \multirow{2}{*}{$\eta^{2}$} & \multirow{2}{*}{ KW } & \multirow{2}{*}{$\begin{array}{c}\text { Multiple } \\
\text { Comparison }\end{array}$} \\
\hline & & & & & & & & 25 & 75 & & & \\
\hline 1. Group & \multirow{3}{*}{$\begin{array}{c}\text { Pre-Assist } \\
\text { Passes in } \mathrm{OZ}\end{array}$} & 6 & 6 & 17 & 7,5 & 11.92 & \multirow{3}{*}{4.21} & \multirow{3}{*}{5.75} & \multirow{3}{*}{10.25} & \multirow{3}{*}{$.48^{\#}$} & \multirow{3}{*}{$10.39 * *$} & \multirow{3}{*}{$\begin{array}{l}1>3 * * \\
2>3 * *\end{array}$} \\
\hline 2. Group & & 6 & 6 & 19 & 9 & 12.75 & & & & & & \\
\hline 3. Group & & 6 & 3 & 6 & 5 & 3.83 & & & & & & \\
\hline 1. Group & \multirow{3}{*}{ Assists in GZ } & 6 & 1 & 3 & 2 & 12.83 & \multirow{3}{*}{.98} & \multirow{3}{*}{.00} & \multirow{3}{*}{2.00} & \multirow{3}{*}{$.73^{\#}$} & \multirow{3}{*}{$7.26^{*}$} & \multirow{3}{*}{$1>3 * *$} \\
\hline 2. Group & & 6 & 0 & 2 & 2 & 10.50 & & & & & & \\
\hline 3. Group & & 6 & 0 & 1 & 0 & 5.17 & & & & & & \\
\hline 1. Group & \multirow{3}{*}{$\begin{array}{l}\text { Free Kick } \\
\text { Goals }\end{array}$} & 6 & 1 & 5 & 3 & 13.92 & \multirow{3}{*}{1.50} & \multirow{3}{*}{.00} & \multirow{3}{*}{2.00} & \multirow{3}{*}{$.83^{\#}$} & & \\
\hline 2. Group & & 6 & 0 & 2 & 1 & 7.67 & & & & & $6.67 *$ & $\begin{array}{l}1>3 * \\
1>2 *\end{array}$ \\
\hline 3. Group & & 6 & 0 & 2 & .50 & 6.92 & & & & & & \\
\hline 1. Group & & 6 & 3 & 12 & 4 & 13.50 & & & & & & \\
\hline 2. Group & Carom Goals & 6 & 0 & 7 & 3.5 & 10.08 & 3.45 & 1.00 & 4.25 & $.65^{\#}$ & $8.10^{*}$ & $1>3 * *$ \\
\hline 3. Group & & 6 & 0 & 2 & 1 & 4.92 & & & & & & \\
\hline 1. Group & & 6 & 0 & 2 & .50 & 12.50 & & & & & & \\
\hline 2. Group & Goals in PPA & 6 & 0 & 0 & .00 & 8.00 & .54 & .00 & .00 & $.53^{\#}$ & $6.75^{*}$ & $\begin{array}{l}1>3 * \\
1>2 *\end{array}$ \\
\hline 3. Group & & 6 & 0 & 0 & .00 & 8.00 & & & & & & \\
\hline 1. Group & & 6 & 7 & 20 & 13 & 13.25 & & & & & & \\
\hline 2. Group & Goal in GZ & 6 & 8 & 16 & 10.50 & 9.92 & 3.77 & 7.75 & 12.50 & $.54^{\#}$ & $6.73 *$ & $1>3 * *$ \\
\hline 3. Group & & 6 & 6 & 11 & 7.50 & 5.33 & & & & & & \\
\hline 1. Group & & 6 & 11 & 31 & 14.50 & 13.67 & & & & & & \\
\hline 2. Group & Goal in $\mathrm{GSZ}_{1}$ & 6 & 7 & 16 & 12 & 10.00 & 5.72 & 7.75 & 14.25 & $.60^{\#}$ & $8.41 *$ & $1>3 * *$ \\
\hline 3. Group & & 6 & 5 & 13 & 7.50 & 4.83 & & & & & & \\
\hline
\end{tabular}

$* * \mathrm{p}<.01 * \mathrm{p}<.05$ 


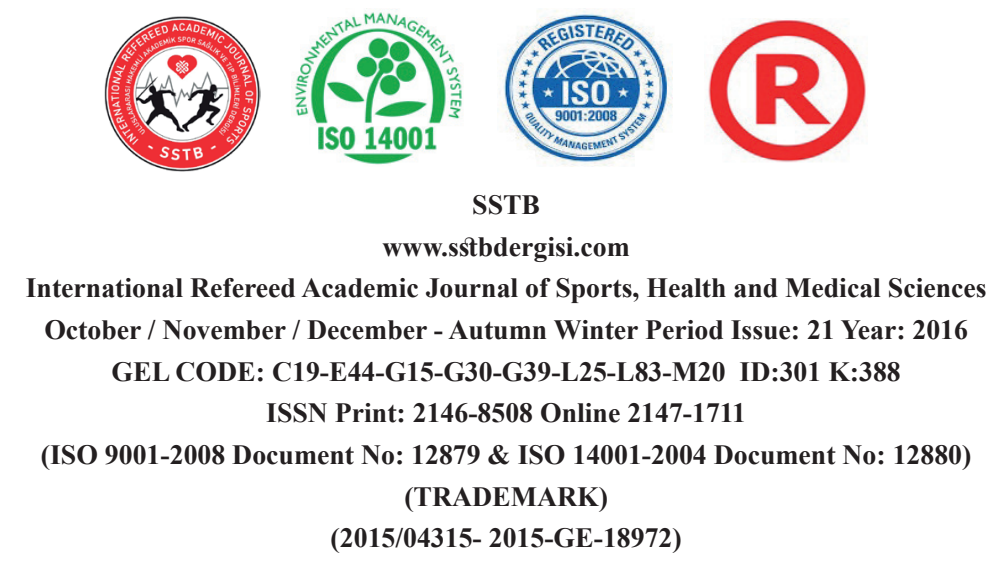

Respectively, $\quad \eta^{2}=0.01 \quad$ Small, $\quad \eta^{2}=0.06$ considered were found to be insignificantly Middle, $\Pi^{2}=0.14$ High, ${ }^{\#} \eta^{2}=0.20$ Very High Effect Size

In Table 1, the distribution of pre-assist passes, assists and goals of teams depending on zones and the goals scored from free kicks and carom was given depending on Kruskal Wallis and Multiple Comparison test. According to the results, the pre-assist passes made by the teams in other zones during the games $\left(\mathrm{KW}=10.39 ; \mathrm{p}<.01 ; \eta^{2}=.48\right)$, the assists made in goal zones $(\mathrm{KW}=7.26$; $\mathrm{p}<.05 ; \eta^{2}=.73$ ), the goals scored from free kicks $\left(\mathrm{KW}=6.67 ; \mathrm{p}<.05 ; \Pi^{2}=.83\right)$, the goals scored from carom positions $(\mathrm{KW}=8.10$; $\mathrm{p}<.05 ; \mathrm{\eta}^{2}=.65$ ), the goals made through the crossed balls $\left(\mathrm{KW}=6.75 ; \mathrm{p}<.05 ; \eta^{2}=.53\right)$, the goals scored from the goal zones $(\mathrm{KW}=6.73$; $\mathrm{p}<.05 ; \eta^{2}=.54$ ), the goals scored from the goal shoot zone $1\left(\mathrm{KW}=8.41 ; \mathrm{p}<.05 ; \mathrm{h}^{2}=.60\right)$ were found to significantly difference with very high effect size for team groups.

According to the multiple comparison of the pre-assist passes made from the other zones, the $1^{\text {st }}$ group of teams which consists of top six teams in the league and the $3^{\text {rd }}$ group which consists of last 6 teams and the $2^{\text {nd }}$ group which consists of the average six teamsin mid-position were found to differ significantly for the benefit of the $1^{\text {st }}$ group and $2^{\text {nd }}$ group $(\mathrm{p}<.01)$. The pre-assist passes made in other zones when team groups were different ( $>$.05). According to the multiple comparison tests of the assists made from the goal zone, the 1 st and the $3^{\text {rd }}$ group of teams were found to significantly differ for the benefit of the $1^{\text {st }}$ group $(\mathrm{p}<.01)$. The assists made in the assists zones when team groups were considered did not suggest any significant difference ( $p>05)$. According to the multiple comparison test results of the goals scored from free kicks, the $1^{\text {st }}$ group and the $2^{\text {nd }}$ and the $3^{\text {rd }}$ group were found to be significantly different for the benefit of the $1^{\text {st }}$ group $(\mathrm{p}<.05)$. According to the multiple comparison test of the goals scored from carom, the $1^{\text {st }}$ group and the $3^{\text {rd }}$ group were found to be significantly different for the benefit of the $1^{\text {st }}$ group $(\mathrm{p}<.01)$. According to the multiple comparison test of the goals scored through the crossed balls, the $1^{\text {st }}$ group and the $2^{\text {nd }}$ group and the $3^{\text {rd }}$ group were found to significantly differ for the benefit of the $1^{\text {st }}$ group $(\mathrm{p}<.05)$. According to the multiple comparison test of the goals scored from the goal zone, the $1^{\text {st }}$ group and the $3^{\text {rd }}$ group were found to significantly differ for the benefit of the $1^{\text {st }}$ group $(p<.01)$. According to the multiple comparison test of the goal shoot zone 1 , the $1^{\text {st }}$ group and the $3^{\text {rd }}$ group were found to significantly differ for the benefit of the $1^{\text {st }}$ group $(\mathrm{p}<.01)$. There has been no significant difference when other goal shoot 


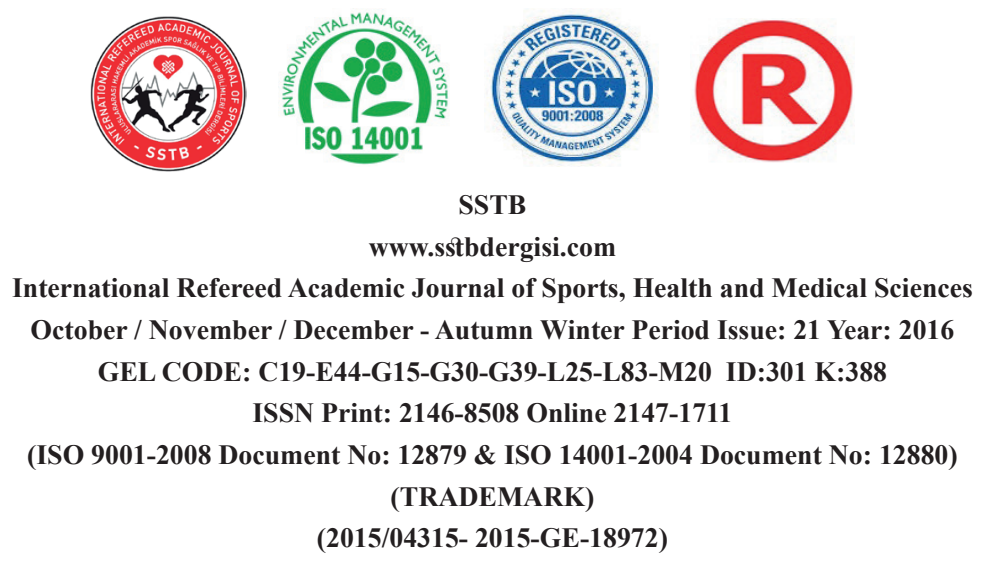

zone were considered for the team groups $(p>.05)$.

\section{RESULTS and DISCUSSION}

The findings of this study suggest that the teams in the league competing for winning the championship or joining the European cups ( $1^{\text {st }}$ group) and the teams in mid-positions of the league ( $2^{\text {nd }}$ group) were found to be better scoring teams from pre-assists passes, assists in goal zone, free kicks, carom and the zones where goal passes are crossed and goal shoot zone 1 compared to the teams competing to stay in the league ( $3^{\text {rd }}$ group). The reason for that may be the teams with higher budgets can transfer more talented players and that they get better scores compared to those teams which lack of such budget.

When we examine the details of the study, the teams in the $1^{\text {st }}$ group were found to be better at scoring goals from the carom positions within the penalty area, free kick goals, goal zone goals and assists in goal zones compared to the teams in the $3^{\text {rd }}$ group. The reason for this may be the teams in the $1^{\text {st }}$ group could organize better offenses into the opponent teams' penalty zones more effectively compared to the teams in the $3^{\text {rd }}$ group. The findings of the studies in the relevant literature suggest that offensive based playing can significantly affect the match results (Winter and Pfeiffer,
2016: 486). They also come up with findings suggesting that goal kicks significantly are done within the penalty areas (İmamoğlu, at. al. 2007: 157). Another study carried out to investigate the goals of the teams competing in UEFA Champions League in 2004-2005, 2005-2006 and 2006-2007 seasons depending on the zones of goal occurrence suggest that great majority of the goals score in three seasons (respectively, 76.4\%, 77,5\% and $77 \%$ ) were scored within the penalty areas (Sönmeyenmakas, 2008: 46). These findings support this study results.

The teams in the $1^{\text {st }}$ group were found to be more effective in the goals scored from free kicks, which are very important in goal scoring in set games (Carling, 2005; 109) and the goals scored from the balls crossed out of the penalty areas compared to the teams in the $2^{\text {nd }}$ and $3^{\text {rd }}$ group. The reason for that may be the players responsible for free kicks are more capable with regards to technical and tactical skills compared to those of the $2^{\text {nd }}$ and $3^{\text {rd }}$ group teams. The shoots on target which were investigated in many studies and which are suggested to be the factors affecting the winning rates in football (Mouraet. A1., 2014: 1886; Göral, 2015: 1107; Lago-Penas et. al., 2010: 288) can be used in explaining for the fact that the teams in the $1^{\text {st }}$ group had better match scores compared to the teams in the $2^{\text {nd }}$ group in this study. 


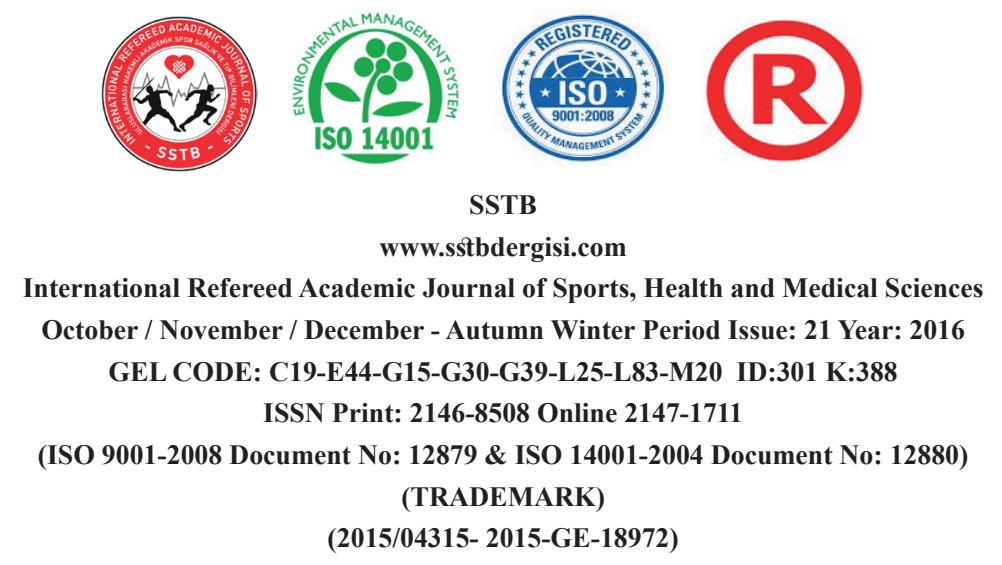

The basic reason for this study to divide the teams in the league into groups for evaluation was to find out how the teams in top ranks differed from those in mid-ranks and lower ranks. That is why; no team-based evaluation was conducted in this study. However, it was found based on the descriptive statistics that the team which winning the championship at the end of the season (Beşiktaş) was better at using the central attack zone compared to the other teams in the league. The team which was at the second rank of the league at the end of the season (Fenerbahçe) was found to be better at short passes into penalty area compared to the other teams including the champion team, Beşiktaş. These findings cannot be suggested as the only factor affecting the success of the top rank teams in the league, but they can be suggested to play important roles in increasing them up to the top ranks in the league.

Further researches need to be conducted in the leagues of various countries to test to what extend these findings show consistency. The evaluation of the pre-assist passes, assist and goal values which were investigated in this study based on their occurrence described by the researchers is the basic limitation of this study. The identification of the rates regarding the offenses ended up with goals and goal attempts for efficiency calculations can be suggested for further studies in the future.
In brief, when the offense diversity in the $3^{\text {rd }}$ zone which is one of the biggest problems of the teams in our country is considered, the research findings are suggested to be a guiding light for trainers and players. The fact that the teams at top ranks are better at using the gold zone within the penalty area compared to those at the bottom ranks can be used to suggest that this play style can offer successful outcomes for trainers and players.

\section{KAYNAKLAR}

ALGHANNAM, A. F., (2012). Metabolic Limitations of Performance and Fatigue in Football. Asian Journal of Sports Medicine, 3(2), pp. 65-73

AŞÇI, A., AK, M., CíHAN, H., (2009). Genç Futbolcularda Aerobik Güç Performansının Yaşa Bağlı Olarak Değerlendirilmesi. 3. Ulusal Futbol ve Bilim Kongresi Bildiri Kitabı. Ankara: BAYT Bilimsel Araştırmalar

BILLTON J., USHER, P., (2014). Analysing the Soccer Player. Ios E-Book

CARLING, C., WILLIAMS, A. M., REILLY, T., (2005). Handbook of Soccer Match Analysis. Abingdon: Routledge

CASTELLANO, J., CASAMICHANA, D., $L A G O, C$., (2012). The Use of Match Statistics That Discriminate between Successful and Unsuccessful Soccer Teams. 


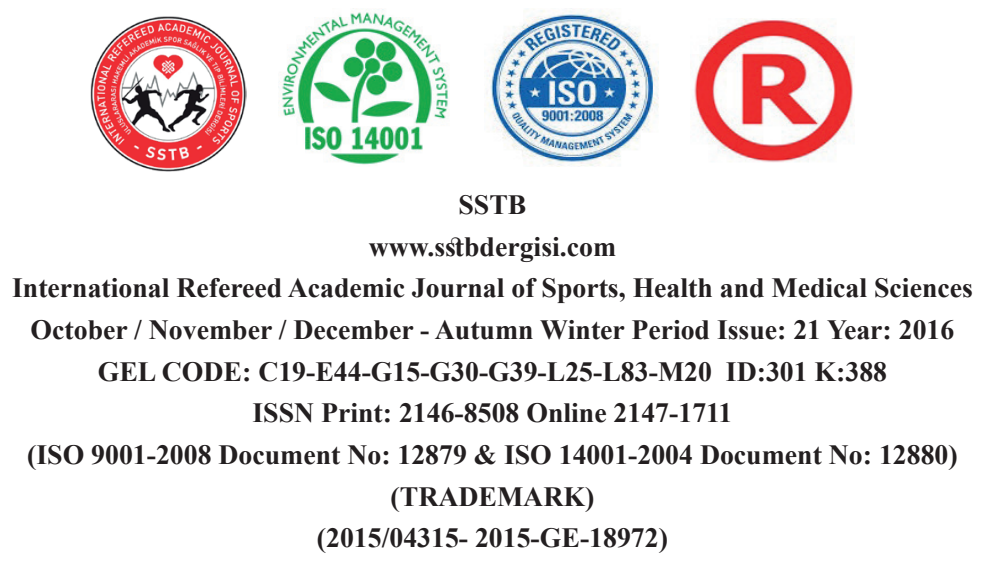

Journal of Human Kinetics, 31, pp.139147

CENGIZZ, D., KILINÇ, B., (2007). Faktör Analizi İle 2006 Dünya Kupası'na Katılan Takımların Siralamasının Belirlenmesi. Marmara Üniversitesi İ.İ.B.F. Dergisi, 23(2), pp. 351-370

CERRAH, A.O., GÜROL, B., (2011). Analysis Of Goal Scored in Turkish 1. Division Soccer Leagues From 2001 to 2009. Türkiye Klinikleri J Sport Sci., 3(2), pp.7985.

DRUST, B., (2009). Different Training Approaches in Football. 3. Ulusal Futbol ve Bilim Kongresi Bildiri Kitabı. Ankara: BAYT Bilimsel Araştırmalar

\section{DE BARANDA P S, LOPEZ-RIQUELME}

D., (2012).Analysis of CornerKicks in Relation to Match Status in the 2006 World Cup. European Journal of Sport Science 12(2), pp.121-129

GÖRAL, K., (2015).Son Şampiyon Alman Milli Takımının 2014 FIFA Dünya Kupas1 Performansının Analizi. Uluslararası İnsan Bilimleri Dergisi, 12(1), pp. 11071117

GÜLER, A., HALICIOĞLU, M. B., TAŞĞIN, S., (2015). Sosyal Bilimlerde Nitel Araştırma. Seçkin Yayıncılık, Ankara
IŞIK, T., GENÇER, R.T., (2007). Basketbolda Takım Performansının Teknik Analizi: İç Saha ve Dış Saha Performanslarının Değerlendirilmesi. Hacettepe J. of Sport Sciences, 18(3), pp.101-108

IMAMÖ̆LU, O., ÇEBİ, M., KILCIGILL, E., (2007). 2006 FIFA Dünya Futbol Kupasındaki Gollerin Teknik ve Taktik Kriterlere Göre Analizi. Spormetre Beden Eğitimi ve Spor Bilimleri Dergisi, 5(4), pp.157-165

IMAMOĞLU, R., BOSTANCI, KABADAYI, M., IMAMOĞLU,M., (2015). 2012-2013 Sezonu Türkiye Spor Toto Süper Liginde Mücadele Eden Takımların Yaptıkları Maç Sonuçlarının Farklı Parametrelere Göre İncelenmesi. International Journal of Science Culture and Sport, Special Issue (4), pp.159-166

LAGO-PENAS, C., LAGO-BALLESTEROS, J., DELLAL, A., GOMEZ, M., (2010). Game-Related Statistics That Discriminated Winning, Drawing and Losing Teams from the Spanish Soccer League. Journal of Sports Science and Medicine, 9, pp.288-293

MOURA, F.A., MARTINS, L.E.B., CUNHA, S.A., (2014). Analysis of Football GameRelated Statistics Using Multivariate Techniques. Journal of Sports Sciences, 32(20), Pp.1881-1887 


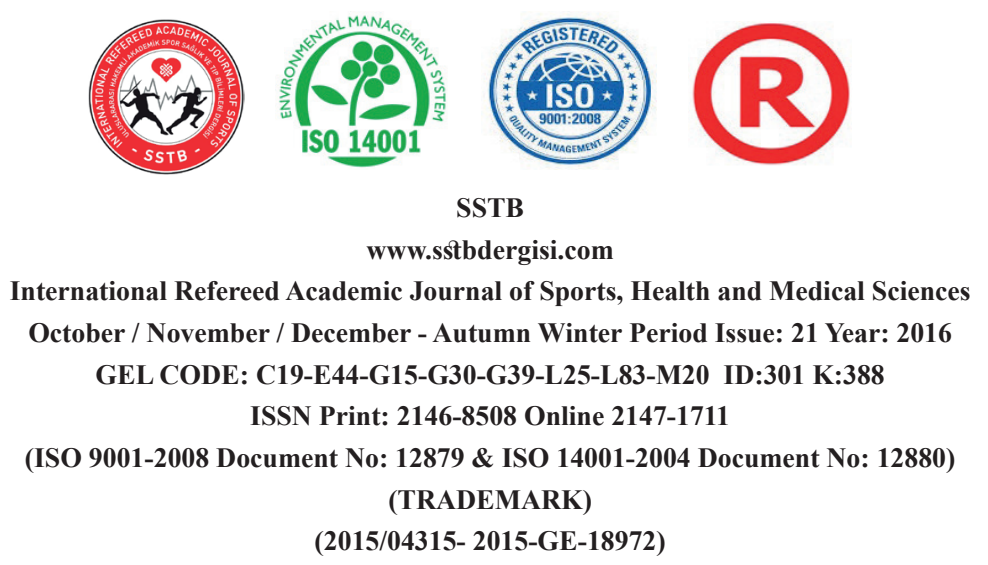

MÜNİROĞLU, S., (2009). Futbolda Müsabaka Analizi ve Gözlemin Önemi. 3. Ulusal Futbol ve Bilim Kongresi Bildiri Kitabi. Ankara: BAYT Bilimsel Araştırmalar

ORENDURFF, M. S., WALKER, J. D., JOVANOVIC, M., TULCHIN, K. L., LEVY, M., HOFFMANN, D. K., (2010). Intensity and Duration of Intermittent Exercise and Recovery during a Soccer Match. J Strength Cond Res., 24(10), Pp.2683-2692

RANKOVIC, G., MUTAVDZIC, V., TOSKIC, D., PRELJEVIC, A., KOCIC, M., NEDIN-RANKOVIC, G., DAMJANOVIC, N., (2010). Aerobic Capacity as an Indicator in Different Kinds of Sports. Bosnian Journal of Basic Medical Sciences, 10(1), pp.44-48

SARMENTO, H., MARCELINO, R., ANGUERA, M. T., CAMPANICO, J., MA-
TOS, N., LEITAO, J. C., (2014).Match Analysis İn Football: A Systematic Review. Journal of Sports Sciences, 32(20), pp.1831-1843

SÖNMEYENMAKAS, A., (2008).Uefa Şampiyonlar Ligi'nde Atılan Gollerin Analizi. Yüksek Lisans Tezi. Trakya Üniversitesi Sağl1k Bilimleri Enstitüsü. Edirne

UĞRAŞ, A., ÖZKAN, H., SAVAŞ, S., (2002). Bilkent Üniversitesi Futbol Takımının 10 Haftalık Ön Hazırlık Sonrasındaki Fiziksel Ve Fizyolojik Karekteristikleri. G.Ü. Gazi Eğitim Fakültesi Dergisi, 22(1), pp.241-252

WiNTER, C., PFEIFFER, M., (2016). Tactical Metrics That Discriminate Winning, Drawing and Losing Teams in UEFA Euro 2012®, Journal of Sports Sciences, 34(6), pp.486-492 